\title{
酸化スズ中のクロムの化学状態と色調の分光学的研究
}

\author{
石田信伍・林 雅彦・加藤育男 \\ (中部大学 工業化学科)
}

\section{Spectroscopic Study of Chemical State and Coloration of Chromium in Tin Oxide}

\author{
Shingo ISHIDA, Masahiko HAYASHI and Ikuo KATO \\ $\left(\begin{array}{c}\text { Department of Industrial Chemistry, Chubu University } \\ \text { Matsumoto-cho, Kasugai-shi } 487\end{array}\right)$
}

\begin{abstract}
Origin of the purple color of chromium-containing $\mathrm{SnO}_{2}\left(\mathrm{Cr}-\mathrm{SnO}_{2}\right)$ was studied mainly by ESCA, ESR and diffuse reflectance spectroscopies. It was found that when the $\mathrm{Cr}_{2} \mathrm{O}_{3}$ content in $\mathrm{Cr}-\mathrm{SnO} \mathrm{O}_{2}$ was higher than 1.5 wt \%, the color of $\mathrm{Cr}-\mathrm{SnO} \mathrm{z}_{2}$ is not purple but green due to the presence of $\mathrm{Cr}^{3+}$ in the aggregate state. ESCA and ESR analyses of the chemical state of chromium in $\mathrm{Cr}-\mathrm{SnO}_{2}$ revealed that $\mathrm{Cr}^{6+}, \mathrm{Cr}^{5+}$ and $\mathrm{Cr}^{3+}$ are minor species when the $\mathrm{Cr}_{2} \mathrm{O}_{3}$ content in $\mathrm{Cr}-\mathrm{SnO} \mathrm{O}_{2}$ was about 0. 2wt\%. Addition of $\mathrm{Al}^{3+}$ or $\mathrm{Sb}^{5+}$ to $\mathrm{Cr}-\mathrm{SnO}_{2}$ gave rise to absorption bands at about 450 and $600 \mathrm{~nm}$ or 470 and $650 \mathrm{~nm}$ respectively, indicating that $\mathrm{Cr}^{5+}$ and $\mathrm{Cr}^{3+}$ in $\mathrm{Cr}-\mathrm{SnO} \mathrm{O}_{2}$ are not responsible for the purple color (570 nm). Consequently, the broad absorption band at $570 \mathrm{~nm}$ was considered to be produced by $\mathrm{Cr}^{4+}$.

[Received April 14, 1986]
\end{abstract}

Key-words : Chromium-containing $\mathrm{SnO}_{2}, \mathrm{Cr}^{4+}$, Color development mechanism, ESCA, ESR

\section{1. 緒 言}

$\mathrm{Cr}$ イオンが $\mathrm{SnO}_{2}$ に固溶する場合, イオンの大きさ1) のみから考えれば, $\mathrm{Sn}^{4+}$ (イオン半径 $r=69 \mathrm{pm}$ ) は 6 配位であるから，主として 6 配位のイオン半径領域にあ る $\mathrm{Cr}^{3+}(r=62 \mathrm{pm})$ 及び $\mathrm{Cr}^{4+}(r=55 \mathrm{pm})$ の形で存 在していると予想される. $\mathrm{Cr}^{5+}(r=49 \mathrm{pm})$ 及び $\mathrm{Cr}^{6+}(r$ $=44 \mathrm{pm})$ は 6 配位の理想半径 $58 \mathrm{pm}$ よりかなり小さい ので, $\mathrm{Cr}^{5+}$ や $\mathrm{Cr}^{6+}$ の形で固溶している $\mathrm{Cr}$ の量は比較 的少ないと考えられる.

誘電率の高い $\mathrm{TiO}_{2}$ には $2 \sim 6$ 価の金属イオンが固溶 することが知られているが2) $\mathrm{SnO}_{2}$ は誘電率が低いの で ${ }^{3), 4)}$ ，局部的な電荷の不均等を補償しにくいと考えら れる. したがって, 電気的中性の原理のみから考えれば, $\mathrm{Cr}^{4+}$ が主要な固溶種となると思われる.

上記二つの立場を考慮すれば, $\mathrm{Cr}$ は主として $\mathrm{Cr}^{4+}$ 及 び $\mathrm{Cr}^{3+}$ の形で $\mathrm{SnO}_{2}$ に固溶すると推定される.

少量の $\mathrm{Cr}$ を含む $\mathrm{SnO}_{2}$ は紫色であり，窯業顔料とし て利用されている. Escribano ら ${ }^{5)}$ は, $\mathrm{Cr}_{2} \mathrm{O}_{3}$ は $\mathrm{SnO}_{2}$ 中 に最大で 17〜29 mol \%固溶し，この試料は緑色を示す ことを報告している. 紫色の $\mathrm{Cr}-\mathrm{SnO}_{2}$ 顔料については, 固溶した $\mathrm{Cr}$ の化学状態や発色の原因について, 言及さ れた報告はなく，現象論的結果以外は何も分かっていな いと言っても過言ではない.

本研究は，ESCA，ESR 及び拡散反射スペクトルの 測定と化学分析を併用して, 各種 $\mathrm{Cr}$ イオンの固溶量及
び色調を調へ，紫色を示す原因について検討したもので ある。

\section{2. 実験方法}

\section{1 試料の調製}

$\mathrm{SnO}_{2}$ に $\mathrm{Cr}$ イオンが均等に混入されることを期待し て, 所定量の $\mathrm{SnCl}_{2}$ と $\mathrm{Cr}\left(\mathrm{NO}_{3}\right)_{3}$ を含む水溶液にアンモ 二ア水を加えて得られた共沈水酸化物を出発物質とし た.これを乾燥後, $500{ }^{\circ} \mathrm{C}$ で 3 時間加熱し $\mathrm{Sn}^{2+}$ を $\mathrm{Sn}^{4+}$ とした後で更に温度を上げて焼成した． $\mathrm{Al}^{3+}$ を添加物 として加える場合は $\mathrm{Al}\left(\mathrm{NO}_{3}\right)$ を $\mathrm{SnCl}_{2}$ と $\mathrm{Cr}\left(\mathrm{NO}_{3}\right)_{3}$ 水 溶液に加えてアンモニア水で共沈させ，また $\mathrm{Sb}^{5+} や$ $\mathrm{Nb}^{5+}$ を添加物として加える場合は $\mathrm{SnCl}_{2}$ と $\mathrm{Cr}\left(\mathrm{NO}_{3}\right)_{3}$ の共沈水酸化物に $\mathrm{Sb}_{2} \mathrm{O}_{3}$ や $\mathrm{Nb}_{2} \mathrm{O}_{5}$ を加え，乳鉢中でよ く混合し，以後同様な操作で焼成した．焼成には白金る つぼを使用し，空気中で行った。この時使用した試薬は $\mathrm{Nb}_{2} \mathrm{O}_{5}$ （純度 $99.9 \%$ ）以外, 特級試薬であった。

焼成した試料は乳鉢で粉砕し，一部はそのまま以後の 測定に供した. また，その一部は表面や粒間の Cr 亿才 ン等を除去するために酸洗浄処理をした. 試料の酸洗浄 は $\mathrm{H}_{2} \mathrm{O} / \mathrm{H}_{2} \mathrm{SO}_{4}=2 / 8$ ( vol 比) の硫酸中に試料を入れ, 約 $200{ }^{\circ} \mathrm{C}$ で 2 時間加熱して行い, 引き続き純水で 5 回以 上洗浄した後乾燥した.

\section{2 化学分析}

$\mathrm{Cr}$ 及び $\mathrm{Al}$ の分析手順を述べる. 試料に $\mathrm{Na}_{2} \mathrm{CO}_{3}$ を加 
えて溶融した後，冷却し希塩酸で溶解した $(0.3 \sim 1 \mathrm{~N})$. この溶液に $\mathrm{H}_{2} \mathrm{~S}$ を通じて, $\mathrm{Sn}$ 及び $\mathrm{Sb}$ を沈殿させ，こ れを沪別する. 沪液を $\mathrm{NaOH}$ で塩基性にして $\mathrm{H}_{2} \mathrm{O}_{2}$ を加 え，これを加熱して $\mathrm{Cr}$ をすべて $\mathrm{Cr}^{6+}$ にする．この溶 液を $420 \mathrm{~nm}$ で比色して $\mathrm{Cr}$ 濃度を決定した。比色後, この溶液に $\mathrm{HCl}$ あるいは $\mathrm{NH}_{4} \mathrm{Cl}$ を加えることにより $\mathrm{pH}$ を下げて, $\mathrm{Al}^{3+}$ を $\mathrm{Al}(\mathrm{OH})_{3}$ として沈殿させ，これ を焼成して $\mathrm{Al}_{2} \mathrm{O}_{3}$ にして重量法で $\mathrm{Al}$ を定量した。

次に $\mathrm{Sb}$ の分析手順を述べる.上述の $\mathrm{H}_{2} \mathrm{~S}$ を通じるこ とにより得た沈殿を濃塩酸に溶解した後加熱して $\mathrm{H}_{2} \mathrm{~S}$ を除去する．溶液を沪過して遊離した硫黄を除去する． この溶液に $\mathrm{KClO}_{3}$ を加えて加熱して $\mathrm{Sb}^{3+}$ を $\mathrm{Sb}^{5+}$ に し，これに $\mathrm{CCl}_{4}$ を数滴加えた後，チ才硫酸ナトリウム 溶液で滴定して Sb 濃度を決定した ${ }^{6)}$.

$\mathrm{Nb}$ は試料を $\mathrm{Na}_{2} \mathrm{CO}_{3}$ で溶融した後，希塩酸で沈殿さ せ, $\mathrm{Nb}_{2} \mathrm{O}_{5}$ にしてひょう量することにより分析した.

\section{3 機器による測定}

ESR 測定はXバンド，室温で行った。マイクロ波の 周波数は波数計で測定した. $g$ 值は $\mathrm{Mn}^{2+}$ マーカーを利 用して計算した。

ESCA 測定は粉末試料を両面テープに固着して行っ た.この測定で使用した励起 X 線源は $\mathrm{Mg} K \alpha$ (1253.6 $\mathrm{eV})$ である. 長時間の測定では試料の色が変化したので, 本実験の場合， Cr の酸化状態に対してX線照射による 影響がないように 30 分以内に測定を終了した。Cr 亿才 ンはこの程度の測定時間では酸化状態に変化がないとみ なすことができる7). 結合エネルギーは試料に付着した 有機炭素の $\mathrm{C} 1 \mathrm{~s}$ ピーク位置を $285.0 \mathrm{eV}$ として校正し た。

反射スペクトルの測定は粉末を石英セルに入れ， $\mathrm{Al}_{2} \mathrm{O}_{3}$ 板を対照として $250 \sim 700 \mathrm{~nm}$ の範囲で行った．反 射スペクトルは反射関数 $\left(f(R)=(1-R)^{2} / 2 R ; R\right.$ : 反射率) で表示すべきであるが，大まかな議論をする ときは $f(R)$ の近似関数である $\log (1 / R)$ で表示した.

\section{3. 実験結果及び考察}

\section{1 クロムースズ系試料焼成時のクロムの挙動}

$\mathrm{Cr}$ イオンの酸化価数と $\mathrm{Cr} 2 \mathrm{p}_{3 / 2} \mathrm{ESCA}$ ピーク位置の 関係はかなり調べられており， $\mathrm{Cr}^{6+} や \mathrm{CrO}_{3}$ は $580 \mathrm{eV}$, $\mathrm{Cr}^{5+}-\mathrm{Cr}^{3+}$ は $577.8 \sim 577.6 \mathrm{eV}$ ，また $\mathrm{Cr}_{2} \mathrm{O}_{3}$ は $577.6 \mathrm{eV}$ の結合エネルギー位置にピークを有することが知られて (る ${ }^{7), 8}$. 図 1 に示されるように比較的低い温度で加熱 した試料では， $\mathrm{Cr} 2 \mathrm{p}_{3 / 2}$ のピークが明りょうに認められ ないが，これは $\mathrm{Cr}$ 濃度が低いためと思われる。しかし， $800{ }^{\circ} \mathrm{C}$ 以上で焼成した試料については $577.5 \mathrm{eV}$ にかな り大きなピークが認められる.これは， $\mathrm{Cr}$ が $\mathrm{SnO}_{2}$ の 表面層に偏析したことによって起こったものと考えられ る. $800{ }^{\circ} \mathrm{C}$ で焼成した試料の $\mathrm{Cr} 2 \mathrm{p}_{3 / 2}$ の結合エネルギー
値が $577.5 \mathrm{eV}$ であったことは，これらに含まれる $\mathrm{Cr}$ が 5 3 価の Cr イオンであることを示す. 酸洗浄後の 試料についても調べたが， $1000{ }^{\circ} \mathrm{C}$ 以上で焼成したもの については,酸洗浄前のものとほとんど変わらなかった。

図 2 はこの試料の $\mathrm{ESR}$ スペクトルを示す. $800{ }^{\circ} \mathrm{C}$ 焼 成の試料では $g=2.7$ 付近にかなり大きな吸収が認めら れる.このピークは $1000{ }^{\circ} \mathrm{C}$ 以上で焼成した試料では認

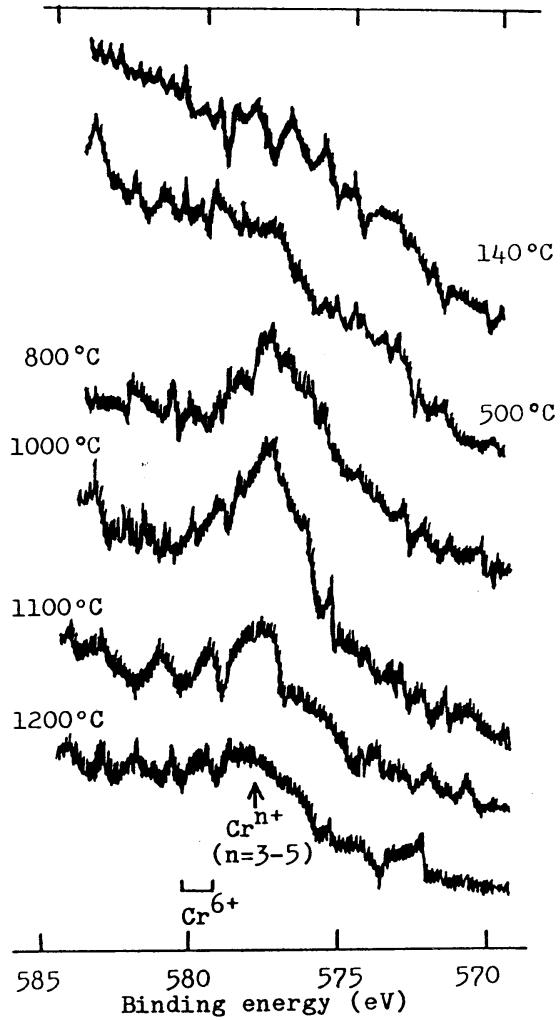

Fig. 1. $\mathrm{Cr}_{2} \mathrm{p}_{3 / 2}$ ESCA spectra of $\mathrm{Cr}-\mathrm{SnO}_{2}$ heated at various temperatures.

Materials: $\mathrm{Sn}(\mathrm{OH})_{2}$ and $\mathrm{Cr}(\mathrm{OH})_{3} \quad\left(\mathrm{Cr}_{2} \mathrm{O}_{3} /\left(\mathrm{Cr}_{2} \mathrm{O}_{3}+\right.\right.$ $\left.\mathrm{SnO}_{2}\right)=0.3 \mathrm{wt} \%$ ),

Heating condition : in air for $90 \mathrm{~min}$,

Samples : before acid leaching treatment

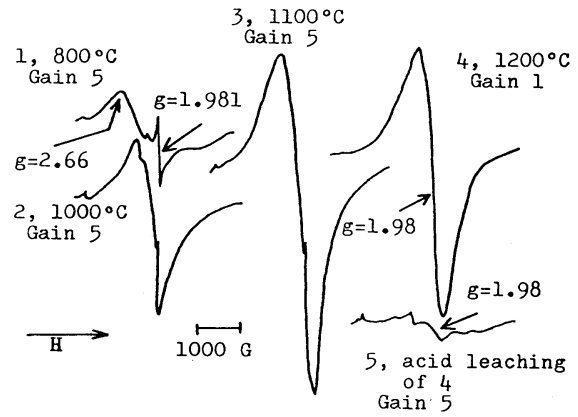

Fig. 2. ESR spectra of $\mathrm{Cr}-\mathrm{SnO}_{2}$ heated at various temperatures.

Samples: the same as described in Fig. 1 
められない. $1200{ }^{\circ} \mathrm{C} て ゙$ 焼成した試料を $500^{\circ} \mathrm{C} て ゙ \mathrm{CO}$ で 還元したとき, このピークが認められたこと, また Cr イオンについて，このような ESR 吸収は報告されてい

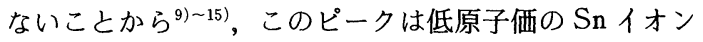
に由来すると考えられる。

$800{ }^{\circ} \mathrm{C}$ で焼成した試料で認められた $g=1.981$ の吸収 は, より高温で焼成した場合消滅した. $\mathrm{Cr}^{5+}$ は $g=2.0$ 〜 1.9 の範囲において, 比較的狭い幅のシグナルを示す ことから ${ }^{11) \sim 13)}, g=1.981$ の吸収は $\mathrm{Cr}^{5+}$ の吸収と帰属 できる.

$1000{ }^{\circ} \mathrm{C}$ 以上の焼成では線幅 $\Delta H_{\mathrm{msl}}$ （msl：maximum slope length，以下線幅は $\Delta H_{\mathrm{ms} 1}$ のことである）が約 $500 \mathrm{G}$ の大きな吸収が現れる. $\mathrm{Cr}^{3+}$ クラスターや $\mathrm{Cr}_{2} \mathrm{O}_{3}$ の微粒子は, $g=2.0 \sim 1.9$ の範囲に約 $500 \mathrm{G}$ の線幅の ESR 吸収を示すから ${ }^{9), 13)}$ ，上記広幅の吸収は凝集状態 の $\mathrm{Cr}^{3+}$ によると帰属される. 図 2 の 4 と 5 の比較から 分かるように，この吸収は酸洗浄によって除去されるの で，これは主として $\mathrm{SnO}_{2}$ 粒子の表面あるいは粒子間の 空げきにあるものと考えられる.

$\mathrm{SnO}_{2}$ に固溶している $\mathrm{Cr}$ の量は酸洗浄処理後の試料 の化学分析により分かる. 表 1 から, Cr 含量が少ない 場合, $1100{ }^{\circ} \mathrm{C}$ 以上の焼成で固溶している $\mathrm{Cr}$ の濃度が減 少していることが分かる.これは既述した ESR の結果 と併せ考えると, $\mathrm{SnO}_{2}$ に固溶していた $\mathrm{Cr}$ イオンが, 粒間や粒子表面に $\mathrm{Cr}_{2} \mathrm{O}_{3}$ あるいはその類似物の形で析 出したり，また使用した電気炬の着色より判断できるこ とであるが，表面の Cr イオンが揮発したためと考えら れる。

出発物質の $\mathrm{Cr}$ 含量を $\mathrm{Cr}_{2} \mathrm{O}_{3}$ に換算して 10 wt \%

Table 1. Contents of chromium in various $\mathrm{Cr}-\mathrm{SnO}_{2}$.

\begin{tabular}{|c|c|c|c|}
\hline sample & $\begin{array}{l}\text { Cr content a) } \\
\text { before firing } \\
\quad \text { (wt } \%)\end{array}$ & $\begin{array}{l}\text { firing } \\
\text { temp; } \\
\left({ }^{\circ} \mathrm{C}\right)\end{array}$ & $\begin{array}{l}\text { Cr content b) } \\
\text { after firing } \\
(\text { wt } \%)\end{array}$ \\
\hline \multirow{3}{*}{$\mathrm{Cr}-\mathrm{SnO}_{2}$} & 0.3 & $\begin{array}{llll} & 8 & 0 & 0 \\
1 & 0 & 0 & 0 \\
1 & 1 & 0 & 0 \\
1 & 2 & 0 & 0\end{array}$ & $\begin{array}{l}0.30 \\
0.29 \\
0.26 \\
0.17\end{array}$ \\
\hline & 0.5 & $\begin{array}{llll} & 8 & 0 & 0 \\
1 & 0 & 0 & 0 \\
1 & 1 & 0 & 0 \\
1 & 2 & 0 & 0\end{array}$ & $\begin{array}{l}0.58 \\
0.28 \\
0.18 \\
0.19\end{array}$ \\
\hline & 10.0 & $\begin{array}{llll} & 8 & 0 & 0 \\
1 & 0 & 0 & 0 \\
1 & 1 & 0 & 0 \\
1 & 2 & 0 & 0\end{array}$ & $\begin{array}{l}3.20 \\
2.76 \\
2.70 \\
2.65\end{array}$ \\
\hline $\mathrm{Al}-\mathrm{Cr}-\mathrm{SnO}_{2}$ & 0.5 & 1200 & 0.10 \\
\hline $\mathrm{Nb}-\mathrm{Cr}-\mathrm{Sn} \mathrm{O}_{2}$ & 0.5 & 1200 & 0.36 \\
\hline $\mathrm{Sb}-\mathrm{Cr}-\mathrm{SnO}_{2}$ & 0.8 & 1200 & 0.45 \\
\hline
\end{tabular}

a) expressed as $\mathrm{Cr}_{2} \mathrm{O}_{3} /\left(\mathrm{SnO}_{2}+\mathrm{Cr}_{2} \mathrm{O}_{3}\right)$

b) expressed as $\mathrm{Cr}_{2} \mathrm{O}_{3}$ content after acid leaching

c) $\mathrm{Al}_{2} \mathrm{O}_{3}$ content $=0.5$ ut\&

d) $\mathrm{Nb}_{2} \mathrm{O}_{5}$ content $=0.2 \mathrm{ut}$

e) $\mathrm{Sb}_{2} \mathrm{O}_{\mathrm{s}}$ content $=3.1 \mathrm{wt} \%$ (mol \%でもほぼ同じ值) と多くした場合でも $\mathrm{SnO}_{2}$ に 固溶している $\mathrm{Cr}$ の量は約 $2.7 \%$ とかなり少なかった。 Escribano ら ${ }^{5)}$ は $\mathrm{Cr}_{2} \mathrm{O}_{3}$ と $\mathrm{SnO}_{2}$ 混合物を $1300{ }^{\circ} \mathrm{C}$ で焼成 した試料を調へ，固溶クロム量は $17 \mathrm{~mol} \%$ 以上であり， また奇妙なことに，このように多量のクロムを固溶して も $\mathrm{SnO}_{2}$ の格子定数には変化が認められないことを報告 している.このことは, $\mathrm{SnO}_{2}$ に固溶しているクロムは それほよ゙多くなく，既述したように $\mathrm{SnO}_{2}$ の表面や粒界 に存在する凝集状態のクロムイオンなどの非晶質物質を 多く含んでいることを示唆しているように思われる。

\section{2 酸化スズに固溶した $\mathrm{Cr}^{3+}$ の ESR 及びその濃度}

図 3 は図 2 No. 5 の酸洗净処理後の試料の ESR スペ クトルを拡大して示したものである. $\mathrm{SnO}_{2}$ 単結晶中の $\mathrm{Cr}^{3+}$ についての ESR 特性値 ${ }^{15)}$ を基にして，周波数 9.38 $\mathrm{GHz}$ のマイクロ波をかけたときに粉末試料で予想され るESR シグナルの位置をよで示した。これと実測のシ グナルがよく一致していることが分かる．表 2 には，磁 場を主軸方向にかけたときの共鳴磁場 ${ }^{16 a)}$ 及び遷移確 率 ${ }^{16 b), 17)}$ の計算結果が示してある.

磁場がかかっている場合, $\mathrm{Cr}^{3+}\left(d^{3}\right)$ はスピン量子数 $S=3 / 2$ であるから，四つのスピン状態に対応したエネ ルギーレベル $\left(W_{1} \cdots W_{4}\right)$ 及び固有関数 $\left(\Psi_{1} \cdots \Psi_{4}\right)$ が定 まる．例えば，磁場 $H$ について $H / / z$ のとき， $\Psi_{i}$ と $\Psi_{j}$ 間の遷移確率はゼロ磁場分離定数 $D, E$ が 0 でない ので, $x$ 方向と $y$ 方向からマイタロ波がかかった場合 は異なる ${ }^{17)}$. したがって，上記の場合の遷移確率 $P$ は， $P=\left\{\left|<\Psi_{j}\right| S_{x}\left|\Psi_{i}>\right|^{2}+\left|<\Psi_{j}\right| S_{y}\left|\Psi_{i}>\right|^{2}\right\} / 2$ で計算した.

いま，極座標で表示して， $\theta ， \varphi$ の角度から磁場をか けたとする. $W_{3} \rightarrow W_{4}$ の遷移は比較的低磁場で起こり,

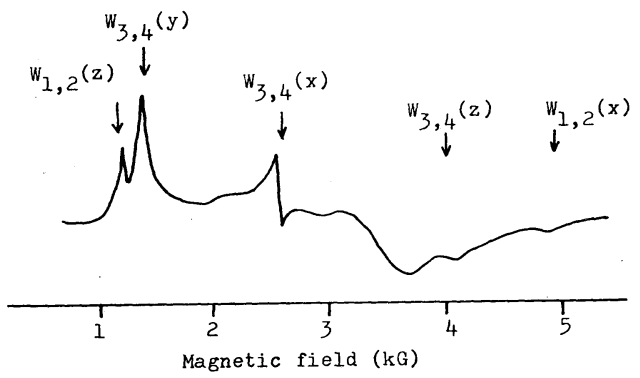

Fig. 3. ESR spectrum of $\mathrm{Cr}^{3+}$ in $\mathrm{SnO}_{2}$.

Measurement condition : room temperature, freq. $=$ 9. $38 \mathrm{GHz}$,

Sample: the same as Fig. 2, No.5; chromium content as $\mathrm{Cr}_{2} \mathrm{O}_{3}=0.17$ wt $\%$

: distinctly observable signal position calculated from single crystal data (W. H. From, Phys. Rev., 131, 961-63 (1963); $g=1.975, D$ $=-21.31, E=-4.43 \mathrm{GHz}$ )

$W_{1,2}(z)$ : transition between the energy levels of $W_{1}$ and $W_{2}$ when the magnetic field is applied parallel to $z$ axis, $W_{1} \ldots W_{4}$ : energy levels for $S=3 / 2$ spin state in increasing order 
かつ $|D|$ に対して $E$ が小さい值なので（図 3 及び表 2 参照）その遷移確率は摂動論で計算できる. 結果のみを 記せば, $P=1 / 2+1 / 2\left(1+3 \sin ^{2} \theta\right)-6 E \cos 2 \varphi$ $\sin ^{2} \theta /|D|\left(1+3 \sin ^{2} \theta\right)$ となる. $H / / z$ では $\bar{P}=1$, $H \| x$ では $P=0.94, H / / y$ では $P=0.31$ と計算され, これらの値は, 表 2 の $W_{3} \rightarrow W_{4}$ の遷移確率の計算值とほ ぼ等しい. $P$ は $H / / y$ で最低であるから, 任意の磁場 方向で 0.3 以上になる. したがって, 図 3 に示した $\mathrm{Cr}^{3+}$ の粉末 ESR スペクトルを 2 回積分して得られる $\mathrm{ESR}$ 吸収強度は $\mathrm{Cr}^{3+}$ と同濃度の $S=1 / 2, g=2$ (遷移 確率 1/4）のそれよりも大であることになる.

0.5 20 kG の範囲で測定した $\mathrm{Cr}^{3+}$.の ESR スペクト ルと $\mathrm{CuSO}_{4} \cdot 5 \mathrm{H}_{2} \mathrm{O}$ の $\mathrm{ESR}$ スペクトルの吸収強度を測 定し, $\mathrm{Cr}^{3+}$ と $\mathrm{Cu}^{2+}$ の 1 個当たりの吸収強度が等しいと 仮定しての比較から, 図 3 の試料に含まれる $\mathrm{Cr}^{3+}$ 濃度 は $\mathrm{Cr}_{2} \mathrm{O}_{3}$ に換算して 0.06 wt \% と計算された.これから， 試料に含まれる全 $\mathrm{Cr}$ 量が $\mathrm{Cr}_{2} \mathrm{O}_{3}$ に換算して $0.17 \mathrm{wt} \%$ であるから， $\mathrm{Cr}^{3+}$ は全 $\mathrm{Cr}$ 量の $35 \%$ 以下であることが 分かる. 上記 $35 \%$ という值は, 遷移確率を実際よりか なり低くみた場合の值であり,また $\mathrm{Cr}^{3+}$ の ESR 吸収 には, $W_{3} \rightarrow W_{4}$ のほかに $W_{1} \rightarrow W_{2}, W_{2} \rightarrow W_{3}$ の吸収や $\mathrm{Cr}^{5+}$ の吸収も混在する. 以上から, $\mathrm{Cr}^{3+}$ や $\mathrm{Cr}^{5+}$ は主要 な固溶種でなく, 大部分の $\mathrm{Cr}$ は通常の測定条件では ESR 測定にかからない種であることが推論される. $\mathrm{Cr}^{4+}$ は液体 $\mathrm{He}$ 温度でのみ ESR 測定が可能であるか $ら^{10), 16 c)}$ ，上述の ESR 測定にかからなかった Cr 種は $\mathrm{Cr}^{4+}$ の可能性が高い.

$\mathrm{Cr}_{2} \mathrm{O}_{3}$ として 1 wt \%の $\mathrm{Cr}$ を含む $\mathrm{SnO}_{2}$ の表面層につ いての化学分析結果によれば, $\mathrm{Cr}$ の平均酸化価数は 3.85 であることが報告されている ${ }^{18)}$.この結果は, $\mathrm{SnO}_{2}$ 中では $\mathrm{Cr}$ は主として $\mathrm{Cr}^{4+}$ として存在するとした 今までの推論と調和する.

\section{3 酸化スズ中のクロムイオンの電子スペクトル}

図 4 は $\mathrm{Cr}$ の濃度を種々変えて焼成した後, 酸洗浄処 理をした試料の拡散反射スペクトルを示したものであ る. $\mathrm{Cr}_{2} \mathrm{O}_{3}$ として $1.5 \mathrm{wt} \%$ 以上の $\mathrm{Cr}$ を含む試料は緑色 を示したが，これらの試料の ESR スペクトルは $g=$

Table 2. Resonant magnetic fields and transition probability for $\mathrm{Cr}^{3+}$ in $\mathrm{SnO}_{2}$.

\begin{tabular}{|c|c|c|c|}
\hline \multirow{2}{*}{ Transition } & \multicolumn{3}{|c|}{ Resonant magnetic field (kG) } \\
\hline & $\mathrm{H} / / \mathrm{z}$ & $H / / x$ & $\mathrm{H} / / \mathrm{y}$ \\
\hline $\begin{array}{c}\mathrm{W}_{1} \rightarrow \mathrm{W}_{2} \\
\text { (probability) }\end{array}$ & $\left(\begin{array}{ll}1.1 & 8 \\
(0.09\end{array}\right)$ & $\begin{array}{r}4.88 \\
(0.98)\end{array}$ & $\left(\begin{array}{cccc}1 & 5 & .0 & 9 \\
(0.8 & 8 & 0\end{array}\right)$ \\
\hline$\underset{\text { (probability) }}{\mathrm{W}_{3} \rightarrow \mathrm{W}_{4}}$ & 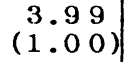 & $\begin{array}{c}2.54 \\
(0.89)\end{array}$ & 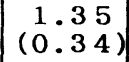 \\
\hline
\end{tabular}

microwave frequency, $g$ value and zero-field splitting constants are the same as described in Fig. 3
1.98 に線幅 $580 \mathrm{G}$ の大きなシグナルを示した.これは $\mathrm{SnO}_{2}$ に囲まれた状態で，凝集状態の $\mathrm{Cr}^{3+}$ があって， これが酸に溶出されないで残っていたことによると思わ れる.これから, Cr 濃度がある程度低くなければ紫色 が発現しないことが分かる.

図 5 は焼成温度と試料の色調の関係を示したものであ る. $500{ }^{\circ} \mathrm{C} て ゙$ 焼成した試料は黄色であったが, これは低 原子価のSnイオンの存在によるものと考えられる. $800{ }^{\circ} \mathrm{C}$ で焼成した試料にも，なお $400 \mathrm{~nm}$ 付近に吸収が 認められ, 黄色味が認められた. $1000{ }^{\circ} \mathrm{C}$ 以上で焼成し たものは紫色を示した。

図 6 は $\mathrm{Al}^{3+}, \mathrm{Sb}^{5+}$ あるいは $\mathrm{Nb}^{5+}$ を添加した $\mathrm{Cr}-\mathrm{SnO}_{2}$ の反射スペクトルを示したものである. $\mathrm{Al}^{3+}$ を添加した場合， 450 及び $600 \mathrm{~nm}$ 付近に新たな吸収が 生じていることが分かる.ルビー $\left(\mathrm{Cr}-\mathrm{Al}_{2} \mathrm{O}_{3}\right)$ の場合, 約 400 と $570 \mathrm{~nm}$ に吸収を示すから ${ }^{19)}$, 上記の 450 及び $600 \mathrm{~nm}$ 付近の吸収は, $\mathrm{Al}_{2} \mathrm{O}_{3}$ に固溶した $\mathrm{Cr}$ イオンによ るものでなく, $\mathrm{SnO}_{2}$ 中の $\mathrm{Cr}$ イオンに由来すると考え られる. 先に, $\mathrm{Cr}$ 濃度が低い場合は $\mathrm{Cr}-\mathrm{SnO}_{2}$ 中の $\mathrm{Cr}$ は主として $\mathrm{Cr}^{4+}$ として存在していると考えたが，これ に更に $\mathrm{Al}^{3+}$ を添加した場合, 電気的中性を保つために,

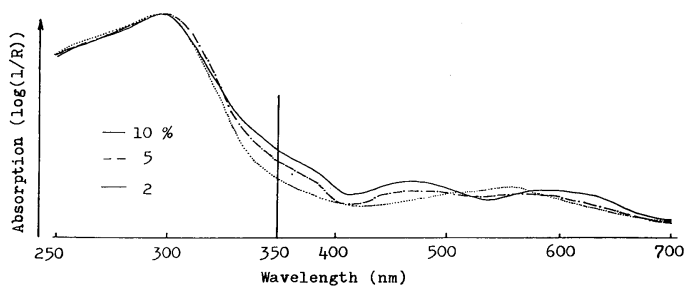

Fig. 4. Reflectance spectra of $\mathrm{Cr}-\mathrm{SnO}_{2}$ with different chromium contents.

Acid-leached samples ; chromium content as $\mathrm{Cr}_{2} \mathrm{O}_{3}: 10$ $\%=2.7 \mathrm{wt} \%, 5 \%=1.5 \mathrm{wt} \%, 2 \%=0.80 \mathrm{wt} \%$, $10(5,2) \%: \mathrm{Cr}$ content in the starting materials expressed as $\mathrm{Cr}_{2} \mathrm{O}_{3} /\left(\mathrm{Cr}_{2} \mathrm{O}_{3}+\mathrm{SnO}_{2}\right)(\mathrm{wt} \%)$,

Firing condition : $1200^{\circ} \mathrm{C}, 90 \mathrm{~min}$, in air

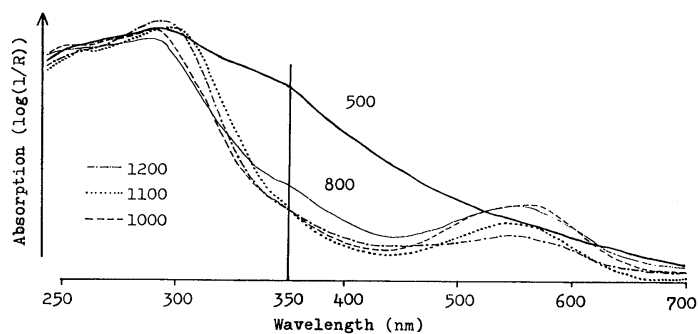

Fig. 5. Reflectance spectra of $\mathrm{Cr}-\mathrm{SnO}_{2}$ fired at various temperatures.

Materials: $\mathrm{Sn}(\mathrm{OH})_{2}$ and $\mathrm{Cr}(\mathrm{OH})_{3} \quad\left(\mathrm{Cr}_{2} \mathrm{O}_{3} /\left(\mathrm{Cr}_{2} \mathrm{O}_{3}+\right.\right.$ $\left.\mathrm{SnO}_{2}\right)=0.3 \mathrm{wt} \%$ ),

Firing condition : heated in air for $90 \mathrm{~min}$, 500-1200 : firing temperature $\left({ }^{\circ} \mathrm{C}\right)$, Acid-leached samples 
$\mathrm{Cr}^{4+}$ が $\mathrm{Cr}^{5+}$ に変わり，その結果上記吸収が出現したも のと推定される.

$\mathrm{SnO}_{2}$ 中の $\mathrm{V}^{4+}$ の $\mathrm{ESR} の g$ 值 ${ }^{20)}$ より, スピン軌道相 互作用定数 $\lambda$ を $130 \mathrm{~cm}^{-1}$ と仮定して, この $\mathrm{V}^{4+}$ の可視 部の吸収位置を推定すると ${ }^{21)}, 420 \mathrm{~nm}\left(d_{x y} \rightarrow d_{z^{2}}\right)$ 及び $580 \mathrm{~nm} \quad\left(d_{x y} \rightarrow d_{x^{2}-y^{2}}\right)$ となる. $\mathrm{Cr}^{5+}$ は $\mathrm{V}^{4+}$ と等電子構 造であるから，同じ様な位置に吸収を示すはずである. ESR の $g$ 值より, 光吸収位置を推定する方法はあまり 正確とは言えないが，とにかく 450 及び $600 \mathrm{~nm}$ 付近の 吸収を $\mathrm{Cr}^{5+}$ のそれと帰属しても不自然でないことが分 かる.

$\mathrm{Cr}-\mathrm{SnO}_{2}$ に $\mathrm{Al}^{3+}$ を添加した試料の $\mathrm{ESR}$ スペクトル を図 7 に示す。これを見ると, 遊離状態の $\mathrm{Cr}^{3+}$ による 吸収は認められず, $g=1.98$, 線幅 $\approx 200 \mathrm{G}$ の吸収のみ が認められる.この広幅の吸収が凝集状態の $\mathrm{Cr}^{3+}$ に由 来している可能性があったので, 液体窒素温度で ESR 測定してみた。もし，この ESR 吸収が反強磁性的性格 の凝集状態の $\mathrm{Cr}^{3+}$ に起因しているものであれば9), 液体 窒素温度では消失するはずであるが, 実験結果では $\mathrm{ESR}$ 吸収強度はあまり変わらず,これより $\mathrm{Cr}^{5+}$ の吸収

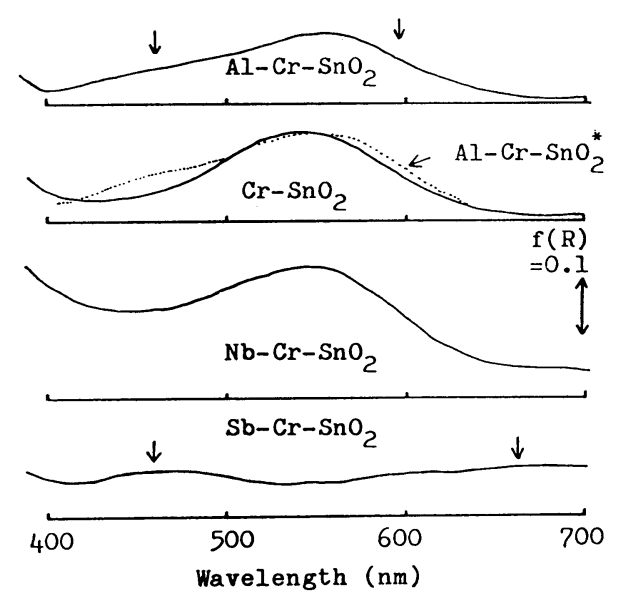

Fig. 6. Reflectance spectra of $\mathrm{Cr}-\mathrm{SnO}_{2}$ doped with $\mathrm{Al}$, $\mathrm{Nb}$ or $\mathrm{Sb}, \mathrm{Al}(\mathrm{Nb}, \mathrm{Sb})-\mathrm{Cr}-\mathrm{SnO}_{2}$ : the same as described in Table 1 ,

$\mathrm{Al}-\mathrm{Cr}-\mathrm{SnO}_{2}^{*}$ : illustrated for comparison in enlarged scale,

$\mathrm{Cr}-\mathrm{SnO}_{2}$ : fired at $1200^{\circ} \mathrm{C}$, chromium content as $\mathrm{Cr}_{2} \mathrm{O}_{3}=$ 0.19 wt\% (after acid leaching),

$f(R)$ : remission function

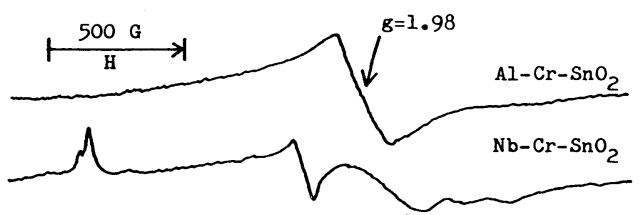

Fig. 7. ESR spectra of $\mathrm{Cr}-\mathrm{SnO}_{2}$ doped with $\mathrm{Al}$ and $\mathrm{Nb}$.

Samples: the same as described in Table 1.
窯業協会誌 95 [3] 1987307

であると帰属される。一般に, $\mathrm{Cr}^{5+}$ の ESR 吸収線幅は 高々 $50 \mathrm{G}\left(\mathrm{Al}_{2} \mathrm{O}_{3} \text { に担持された } \mathrm{Cr}^{5+} \approx 40 \mathrm{G}\right)^{11)}$ であるが, このように広幅なのは $\mathrm{Sn}$ の核スピンの影響によるもの であろう。

図 7 には $\mathrm{Nb}$ を添加した $\mathrm{Cr}-\mathrm{SnO}_{2}$ の $\mathrm{ESR}$ スペクトル が併示してある.このスペクトルには, $\mathrm{Nb}^{4+}$ に由来す ると考えられる ESR シグナルは認められない.この試

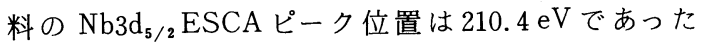
が，これは $\mathrm{Nb}_{2} \mathrm{O}_{5}$ のそれの $210.3 \mathrm{eV}$ に極めて近く, $\mathrm{NbO}_{2}$ のそれの $206 \mathrm{eV}$ と大きく離れていた22). したがっ て, この場合, $\mathrm{Nb}$ は $\mathrm{Nb}^{5+}$ として固溶しているものと 考えられる.

$\mathrm{Sb}$ を添加した $\mathrm{Cr}-\mathrm{SnO}_{2}$ については, 導電性が高いた めか, ESR 測定はできなかった。 なお, $\mathrm{Sb}$ は $\mathrm{SnO}_{2}$ $\mathrm{Sb}^{5+}$ として固溶することが明らかにされている ${ }^{23)}$.

図 6 に戻るが， $\mathrm{Nb}^{5+}$ や $\mathrm{Sb}^{5+}$ を含む $\mathrm{Cr}-\mathrm{SnO}_{2}$ は 470 及び $650 \mathrm{~nm}$ 付近に吸収を示す.これは 5 価イオンの添 加による $\mathrm{Cr}^{3+}$ 濃度の増大に起因すると考えられる.

以上の議論から分かるように, $570 \mathrm{~nm}$ の吸収は $\mathrm{Cr}^{5+}$ や $\mathrm{Cr}^{3+}$ によるものではない. 既述した ESCA や ESR の結果を併せ考えると, $570 \mathrm{~nm}$ の吸収は $\mathrm{Cr}^{4+}$ によるも のとしか考えられない.

著者らは先に， Crを含むスズ-スフェーン $\left(\mathrm{CaO} \cdot \mathrm{SnO}_{2} \cdot \mathrm{SiO}_{2}\right)$ の $525 \mathrm{~nm}$ の吸収は正方対称場の 歪みを受けた正八面体結晶場にある $\mathrm{Cr}^{4+}$ に由来するこ とを明らかにした ${ }^{24)}$. $\mathrm{SnO}_{2}$ 中の $\mathrm{Sn}^{4+}$ はスズースフェ一 ンの場合と同様な歪んだ正八面体結晶場にあるから ${ }^{20)}$, $\mathrm{Sn}^{4+}$ を置換した $\mathrm{Cr}^{4+}$ は500〜600 nm の範囲に同様な吸 収を示すと考えられる，以上から，570 nm の吸収は $\mathrm{Cr}^{4+}$ によるものと結論される.

\section{文献}

1) R. D. Shannon, Acta Cryst., A32, 751-67 (1976).

2）伊達宗行, “電子スピン共鳴”, 培風館 (1978) p. 128.

3) H. J. van Daal, J. Appl. Phys., 39, 4467-69 (1968).

4) R. Summitt, ibid., 39, 3762-67 (1968).

5) P. Escribano, M. C. Guillem and C. Guillem, Trans. J. Brit. Ceram. Soc., 82, 208-10 (1983).

6) N. H. Furman, "Standard Methods of Chemical Analysis", D. van Nostrand Co., Inc. (1962) p. 96-97.

7) Y. Okamoto, M. Fujii, T. Imanaka and S. Teranishi, Bull. Chem. Soc. Jpn., 49, 859-63 (1976).

8) S. A. Best, R. G. Squire and R. A. Walton, J. Catal., 47, 292-99 (1977).

9) D. E. O'Reily, “Adv. in Catal., Vol. 12", Acad. Press (1960) p. 31-111.

10) R. H. Hoskins and B. H. Soffer, Phys. Rev., 133A, 490-93 (1964).

11) L. L. van Reijen and P. Cossee, Disc. Faraday Soc., 41, 277-89 (1966).

12) A. Clark, "Catal Rev., Vol. 3", Marcell Dekkar (1970) p. 145-73.

13) D. D. Beck and J. H. Lunsford, J. Catal. , 68, 121-31 (1981).

14) D. Cordischi, J. C. Vickermann and A. Cimino, Trans. 
Faraday Soc. , 66, 1312-21 (1970).

15) W. H. From, Phys. Rev., 131, 961-63 (1963).

16) J. W. Orton, "Electron Paramagnetic Resonance", Pitman Press (1968); a) p. $51-58$, b) p. $75-84$, c) p. 194-95.

17）児玉万千代, “新実験化学講座 3, 磁気”, 丸善 (1976) p. 221-26.

18) F. Solymosi and J. Kiss, J. C. S. Chem. Comm., 1974, 509-10 (1974).

19) A. S. Marufunin, "Physics of Minerals and Inorganic Materials”, Springer-Verlag (1979) p. 210.
20) C. Kikuchi and I. Chen, J. Chem. Phys., 42, 181-85 (1965).

21) H. G. Hecht and T. S. Johnston, ibid., 46, 23-34 (1967).

22) P. C. Karukar and J. E. Nordman, J. Vac. Sci. Technol., 17, 462-65 (1980).

23) J. L. Portfaix, P. Bussiere and M. Forissier, J. C. S, Faraday I, 76, 1652-59 (1980).

24) S. Ishida, S. Kanaoka, I. Kato and M. Hayashi, Yogyo-Kyokai-Shi, 94, 457-63 (1986). 